\section{Influence of Volume and Activation Mode on Polymerization Shrinkage Forces of Resin Cements}

Sergio Kiyoshi Ishikiriama, Rafael Massunari Maenosono, Denise Ferracioli Oda, Juan Fernando Ordóñez-Aguilera, Linda Wang, Rafael Francisco Lia Mondelli
Department of Operative Dentistry, Endodontics and Dental Materials, Bauru School of Dentistry, USP - University of São Paulo, Bauru, SP, Brazil

Correspondence: Prof. Dr. Sergio Kiyoshi lshikiriama, Alameda Octávio Pinheiro Brisolla, 9-75, Vila Universitária, 17012-901 Bauru, SP, Brasil. Tel: +55-14-32358365. e-mail: serginho@usp.br
The concern with the polymerization shrinkage of restorative resin composites also applies to resin cements. The aim of this study was to evaluate the influence of volume and polymerization mode on forces generated during polymerization shrinkage (FGPS) of resin cements. Two light-cured resin cements - Variolink II (VL; Ivoclar Vivadent) and Nexus 3 (NX; Kerr) - and two self-cured resin cements - Multilink (ML; Ivoclar Vivadent) and Cement Post (CP; Angelus) - were inserted between two rectangular steel bases (6x2 $\mathrm{mm}$ ) with distance set at $0.1,0.3$ and $0.5 \mathrm{~mm}$, establishing a variation of volume. These steel bases were attached to a universal test machine with $50 \mathrm{~kg}$ load cell and forces $(\mathrm{N})$ were registered for $10 \mathrm{~min}$. Values of maximum forces generated by each material were subjected to two-way ANOVA and Tukey's test for individual comparisons $(\alpha=0.05)$. VL, $\mathrm{NX}$ and CP developed increasing FGPS as the volume of material increased, while ML presented the opposite behavior. It may be concluded that higher volume increases FGPS even with a concomitant decrease of $\mathrm{C}$-factor, unless the resin cements present lower force generation rates as a function of time in combination with a low $\mathrm{C}$-factor, resulting in stress relief and consequently lower values of FGPS.
Key Words: resin cement, dental stress analysis, polymerization.

\section{Introduction}

The evolution of indirect restorative systems has widened their indications (1), increasing the importance of luting procedures that promote adhesion, durability and aesthetics. For this reason, resin cements became even more relevant, since this group of materials provides improved physical properties and aesthetics $(2,3)$.

Despite these advantages, the use of resin materials requires some care, especially as regards polymerization shrinkage. Studies with restorative resin composites found that forces generated during polymerization shrinkage (FGPS) can affect the bond strength between tooth and restoration (4) causing cracks, plaque accumulation and even loss of restoration.

Some factors can modify or influence the development of FGPS, among which the cavity configuration factor (C-factor), volume of material and polymerization mode have been intensively studied (5-10). Higher C-factor may increase the intensity of FGPS due to the smaller amount of free surface available for stress relief during the polymerization process (6), while higher volume of material may also increase FGPS due to the greater amount of monomers forming polymeric chains (8). Volume is considered especially important for light-cured restorative resin composite, in which the pre-gel phase is shorter and may not allow stress relief even with a lower C-factor. Stress relief is time-dependent, and the shorter time for polymerization process is responsible for generation of higher forces of light-cured resin composites when compared with the self-cured resin composites (11).

In this context, the role of volume and polymerization mode on a luting procedure (high $\mathrm{C}$-factor) with resin cement are still not well established, and a better understanding of the effect of these factors on the generation of FGPS is essential to avoid failures caused by disruption of adhesive bonding. The objective of this study was to evaluate the influence of the volume and activation mode on FGPS of resin cements. The tested null hypothesis was that neither the volume nor the activation system of polymerization reaction may influence the FGPS of resin cements.

\section{Material and Methods}

This in vitro study involved the analysis of two factors: volume (three levels) and material (four levels). The response variable was determination of the force.

Resin cements used in this experiment, their composition and activation modes are listed in Table 1.

In order to capture the FGPS of resin cements, two rectangular steel bases $(6 \times 2 \mathrm{~mm})$ previously blasted with aluminum oxide were connected to the universal testing machine (Emic DL 500; Emic Equipamentos e sistemas de Ensaios. Ltda, São José dos Pinhais, PR, Brazil) (12). Only Multilink (ML), a ceramic primer without excesses, 
was brushed on the surfaces of the steel bases, in order to ensure polymerization of the material. According to manufacturer, the primer introduces components for polymerization reaction.

The upper steel base was attached to a $50 \mathrm{~kg}$ load cell connected to the movable arm and the bottom steel base was attached to a fixed base (Fig. 1). Distance between bases was set at $0.1,0.3$ and $0.5 \mathrm{~mm}$ determining a variation of volume and $\mathrm{C}$-factor simultaneously (Table 2). C-factor was calculated by the ratio between free and bonded surfaces.

Fifteen specimens for each resin cement, five for each volume $(n=5)$, were prepared in accordance to manufacturer's instructions and set between the steel bases. For dual cured resin cements, the beginning of force registration coincided with the start of light activation, which was performed with a LED light source (Blue Star 3; Microdont, São Paulo, SP, Brazil) for 20 s, with power density (irradiance) of $1,100 \mathrm{~mW} / \mathrm{cm}^{2}$. For self-cured resin cements,

\section{B}

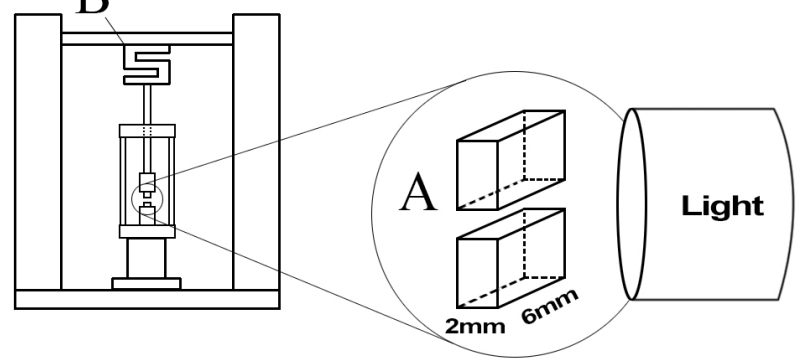

Figure 1. Resin cements were inserted between two rectangular steel bases $(A)$ connected to the universal testing machine with a $50 \mathrm{~kg}$ load cell (B). For dual-cured resin cements, light activation was performed on the 6-mm side of the steel base, allowing the transmission of light to the full extent of the specimen. the beginning of force registration was immediately after their insertion between steel bases.

During polymerization of resin cements, forces generated between the steel bases were recorded continuously for $10 \mathrm{~min}$, resulting in a chart of force $(\mathrm{N})$ $x$ time (s) (Fig. 2).

Values of maximum force generated by each material have been subjected to two criteria analysis of variance with any individual differences pointed by Tukey's test $(p<0.05)$.

\section{Results}

Means and standard deviations of maximum FGPS of all groups are expressed in Table 3. Three of four resin cements developed increasing FGPS as the volume of material increased. Only ML had the opposite behavior: lower FGPS was generated as the volume increased.

Analyzing charts representing the FGPS (Fig. 2), it may be seen that light-cured cements showed a rapid and immediate induction of contraction forces, coinciding with light activation, and a peak contraction coincident with the light shutdown and consequent cooling of material. Cement Post (CP) presented similar behavior with forces being induced immediately after handling and insertion of material between the bases.

Table 2. Distance between steel bases determining a variation of volume and C-factor

\begin{tabular}{lcc}
\hline Distance between steel bases & Volume & C-factor \\
\hline $0.1 \mathrm{~mm}$ & $1.2 \mathrm{~mm}^{3}$ & 15 \\
$0.3 \mathrm{~mm}$ & $3.6 \mathrm{~mm}^{3}$ & 5 \\
$0.5 \mathrm{~mm}$ & $6.0 \mathrm{~mm}^{3}$ & 3 \\
\hline
\end{tabular}

Table 1. Composition and activation mode of resin cements

\begin{tabular}{lcc}
\hline Material & Composition & $\begin{array}{c}\text { Activation } \\
\text { mode }\end{array}$ \\
\hline $\begin{array}{l}\text { Variolink } 11(\mathrm{VL}) \\
\text { lvoclar, Vivadent, Liechtenstein }\end{array}$ & $\begin{array}{c}\text { Bis-GMA, UDMA, TEGDMA, barium glass, ytterbium trifluoride, } \\
\text { Ba-Al-fluorosilicate glass, spheroid mixed oxide. } \\
\text { Additional contents: catalysts, stabilizers, and pigments. }\end{array}$ \\
$\begin{array}{l}\text { Nexus } 3(\mathrm{NX}) \\
\text { Kerr Corp., Orange, CA, USA }\end{array}$ & $\begin{array}{c}\text { Uncured methacrylate ester monomers, lnert mineral fillers, } \\
\text { activators and stabilizers, radiopaque agent }\end{array}$ \\
$\begin{array}{l}\text { Multilink (ML) } \\
\text { lvoclar, Vivadent, Liechtenstein }\end{array}$ & Automix: Dimethacrylate, HEMA, barium glass, ytterbium trifluoride, spheroid mixed oxide \\
Primer A: Aqueous solution of initiators & Self curing \\
Cement Post (CP) & Primer B: HEMA, phosphonic acid, acrylic acid monomers \\
Angelus, Curitiba, PR, Brazil & Base Paste: Bis-GMA, TEGDMA, barium glass ceramic, fumed \\
& silica, tertiary amine, antioxidant, pigments \\
\hline
\end{tabular}

Composition information provided by manufacturers. Bis-GMA = Bisphenol A glycidyl methacrylate; UDMA = Urethane dimethacrylate; HEMA = 2-hydroxyethyl methacrylate; TEGDMA = Triethylene glycol dimethacrylate. 


\section{Discussion}

Polymerization shrinkage forces are able to break adhesive links between resin composite and tooth, causing cracks, plaque accumulation and even loss of restoration (4). Due to the increased use of resin cements, the FGPS of these materials have been investigated $(7,13-15)$.

The most used method to investigate FGPS was originally described by Feilzer et al. (6) wherein the values of FGPS are based on the deformation of a load cell. Variations of equipment, shape and pretreatment of the steel bases were proposed to provide more reliable results, although there is still no consensus in the literature $(5,7,16)$. The present study used a methodology where two aligned rectangular steel bases determined different volumes and C-factor at the same time, varying the distance between them. The upper steel base was attached to a load cell, and its deformation during polymerization shrinkage provided accurate values of FGPS with low standard deviation (12).

The tested null hypothesis was rejected for this study, since increasing volume resulted in a gradual increase of FGPS in three of four resin cements (VL, NX and CP) despite the decreasing values of $\mathrm{C}$-factor. These materials had similar behavior to that of light-activated restorative resin composites $(8,17)$, where the faster polymerization reaction caused by light activation did not allow for stress relief even with lower C-factor values (18-20).

Table 3. Maximum force $(\mathrm{N})( \pm$ standard deviation) reached during the polymerization shrinkage of specimens in different volume/C-factor

\begin{tabular}{lccc}
\hline Volume/C-factor & $1.2 \mathrm{~mm}^{3} / 15$ & $3.6 \mathrm{~mm}^{3} / 5$ & $6.0 \mathrm{~mm}^{3} / 3$ \\
\hline Variolink 1l (dual cured) & $7.85 \pm 0.50(\mathrm{Aa})$ & $9.34 \pm 0.80(\mathrm{Ba})$ & $13.09 \pm 0.93(\mathrm{Cb})$ \\
Nexus 3 (dual cured) & $9.65 \pm 0.43(\mathrm{Ab})$ & $11.43 \pm 0.36(\mathrm{Bb})$ & $12.45 \pm 0.39(\mathrm{Cab})$ \\
Multilink (self cured) & $21.91 \pm 1.00(\mathrm{Ad})$ & $15.59 \pm 0.61(\mathrm{Bc})$ & $11.87 \pm 7.42(\mathrm{Ca})$ \\
Cement Post (self cured) & $14.56 \pm 0.39(\mathrm{Ac})$ & $18.90 \pm 0.47(\mathrm{Bd})$ & $20.57 \pm 0.48(\mathrm{Cc})$ \\
\hline
\end{tabular}

Different uppercase letters in the columns and lowercase letters in the rows indicate statistically significant difference $(\mathrm{p}<0.05)$.
Feilzer et al. (11) attributed higher FGPS values of lightcured resin composites to the lower flow capacity during polymerization process.

Although the increasing volume associated with gradual increase of FGPS is a common characteristic of lightcured resin composites, only one self-cured resin cement presented a similar behavior (Cement Post). A possible explanation to this fact is the high FGPS rate as function of time presented by this resin cement, which probably avoided stress relief even with lower $\mathrm{C}$-factor. An opposite behavior could be observed for the other self-cured resin cement (Multilink). The characteristic of slower polymerization reaction of this material results in lower FGPS, as more free surfaces were available for stress relief (5).

Apart from the different behavior, self-cured resin cements presented high values of FGPS. Probably, even for the groups with reduced C-factor, the free surfaces were insufficient to promote enough stress relief. According to Feilzer et al. (6), a C-factor value higher than 2 may result in FGPS able to compromise dentin/resin bond, and may be considered a high $\mathrm{C}$-factor. In the present study, despite the variations of $\mathrm{C}$-factor, all values were higher than 2, which might cause the high FGPS values. It is likely that with a lower $\mathrm{C}$-factor, self-cured resin cements could provide lower values of FGPS, however, these conditions are not possible in a luting procedure.

Within the limitations of this study, it is possible to conclude that higher volume determines an increase on FGPS of resin cements, even with a concomitant decrease of $\mathrm{C}$-factor. When resin cements with lower rate of force generation as a function of time are combined with a low
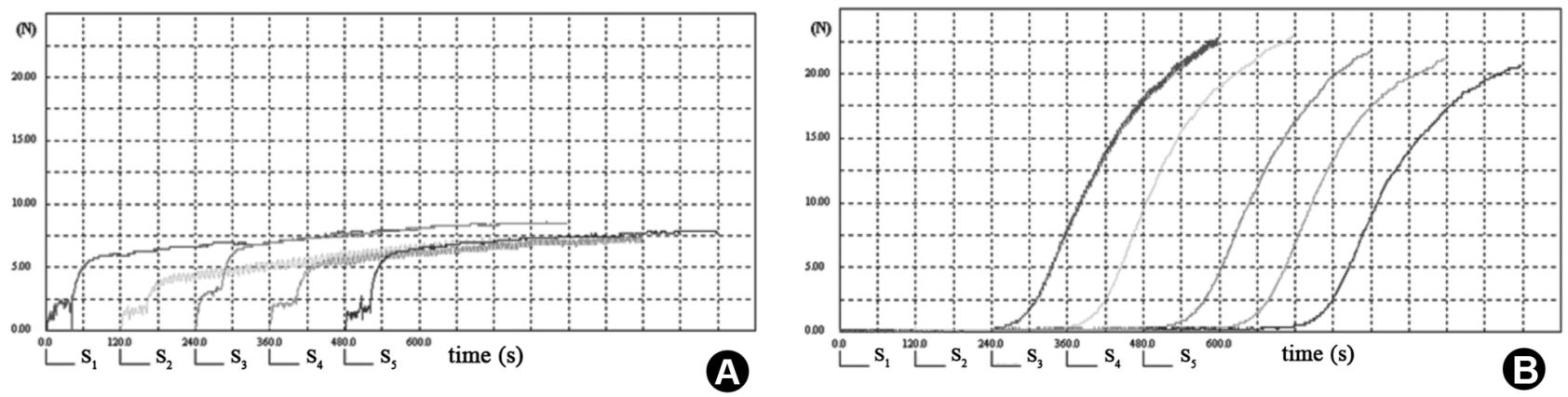

Figure 2. Charts representing the tensions generated during the polymerization shrinkage of dual (A) and self-cured (B) resin cements. * $\mathrm{S}=\mathrm{Specimen}$. 


\section{C-factor, stress relief and consequently lower FGPS values can be obtained.}

\section{Resumo}

Preocupação com a contração de polimerização de resinas compostas restauradoras também tem sido associada aos cimentos resinosos. 0 objetivo deste artigo foi avaliar a influência do volume e do modo de polimerização sobre as forças geradas durante a contração de polimerização (FGPS) de cimentos resinosos. Dois cimentos de ativação dual: Variolink II (VL - Ivoclar Vivadent) e Nexus 3 (NX - Kerr) e dois de ativação quimica: Multilink (ML - Ivoclar Vivadent) e Cement Post (CP - Angelus) foram inseridos entre as duas bases de aço retangulares (6x2 $\mathrm{mm}$ ) com a distância ajustada em 0,1,0,3 e 0,5 mm, estabelecendo uma variação no volume. Estas bases de aço foram fixadas a uma máquina de teste universal (Emic DL 500, com célula de carga de $50 \mathrm{~kg}$ ) e as forças (N) foram registradas por $10 \mathrm{~min}$. Os valores máximos de tensões geradas por cada material foram submetidas à ANOVA a dois critérios, seguido do teste de Tukey $(p<0,05)$ para comparações individuais. VL, NX e CP desenvolveram maiores FGPS quando o volume de material aumentou, enquanto $\mathrm{ML}$ apresentou o comportamento inverso. Maiores volumes aumentam as FGPS mesmo com redução concomitante do Fator- $C_{\text {, a }}$ menos que o cimento resinoso apresente uma baixa taxa de geração de força em função do tempo associado a um baixo Fator- $C_{\text {, o que resulta }}$ em alivio das tensões e consequentemente menores valores de FGPS

\section{References}

1. Kelly JR, Benetti P. Ceramic materials in dentistry: historical evolution and current practice. Aust Dent J 2011;56:84-96.

2 Medina ADC, Paula AB, Fucio SBP, Puppin-Rontani RM, Correr-Sobrinho $L$, Sinhoreti MAC. Marginal adaptation of indirect restorations using different resin coating protocols. Braz Dent J 2012;23:672-678.

3. Haddad MF, Rocha EP, Assuncao WG. Cementation of Prosthetic Restorations: From Conventional Cementation to Dental Bonding Concept. J Craniofac Surg 2011;22:952-958.

4. Ilie N, Kunzelmann K-H, Hickel R. Evaluation of micro-tensile bond strengths of composite materials in comparison to their polymerization shrinkage. Dent Mater 2006;22:593-601.

5. Watts DC, Satterthwaite JD. Axial shrinkage-stress depends upon both C-factor and composite mass. Dent Mater 2008;24:1-8.

6. Feilzer AJ, Degee AJ, Davidson CL. Setting stress in composite resin in relation to configuration of the restoration. J Dent Res 1987;66:16361639.
7. Braga RR, Ferracane JL, Condon JR. Polymerization contraction stress in dual-cure cements and its effect on interfacial integrity of bonded inlays. J Dent 2002;30:333-340.

8. Braga RR, Boaro LCC, Kuroe T, Azevedo CLN, Singer JM. Influence of cavity dimensions and their derivatives (volume and ' $\mathrm{C}$ ' factor) on shrinkage stress development and microleakage of composite restorations. Dent Mater 2006;22:818-823.

9. Pires-de-Souza F de C, Drubi Filho B, Casemiro LA, Garcia L da F, Consani S. Polymerization shrinkage stress of composites photoactivated by different light sources. Braz Dent J 2009;20:319-324.

10. Ishikiriama SK, Valeretto TM, Franco EB, Mondelli RF. The influence of "C-factor" and light activation technique on polymerization contraction forces of resin composite. J Appl Oral Sci 2012;20:603-606.

11. Feilzer AJ, Degee AJ, Davidson CL. Setting stresses in composites for 2 different curing modes. Dent Mater 1993;9:2-5.

12. Pereira RA, de Araujo PA, Castañeda-Espinosa JC, Mondelli RF. Comparative analysis of the shrinkage stress of composite resins. J Appl Oral Sci 2008;16:30-34.

13. Cabrera $E$, de la Macorra JC. Effects of polymerization contraction on interface's mu TBS of luting material and dentin. Clin Oral Investig 2010;14:207-216.

14. May LG, Kelly JR, Bottino MA, Hill T. Effects of cement thickness and bonding on the failure loads of CAD/CAM ceramic crowns: Multi-physics FEA modeling and monotonic testing. Dent Mater 2012;28:E99-E109

15. Ozcan $M$, Mese A. Adhesion of conventional and simplified resinbased luting cements to superficial and deep dentin. Clin Oral Investig 2012:16:1081-1088.

16. Watts DC, Marouf AS. Optimal specimen geometry in bonded-disk shrinkage-strain measurements on light-cured biomaterials. Dent Mater 2000;16:447-451.

17. Watts DC, Marouf AS, Al-Hindi AM. Photo-polymerization shrinkagestress kinetics in resin-composites: methods development. Dent Mater 2003;19:1-11.

18. Mehl A, Hickel $R$, Kunzelmann KH. Physical properties and gap formation of light-cured composites with and without 'softstartpolymerization. J Dent 1997;25:321-230.

19. Unterbrink GL, Muessner R. Influence of light-intensity on 2 restorative systems. J Dent 1995;23(3).

20. Jongsma LA, Kleverlaan CJ, Pallav P, Feilzer AJ. Influence of polymerization mode and $\mathrm{C}$-factor on cohesive strength of dual-cured resin cements. Dent Mater 2012;28:722-728.

Received November 16, 2012 Accepted April 16, 2013 